\section{Updating the Green Revolution}

\section{BY DAVID SPURGEON}

Perhaps the most important problem facing agricultural scientists in the decades ahead is how to keep production of staple foods like rice abreast of population increase in the Third World. In Asia alone, something like 5 million tons of rice will have to be produced every year to keep up with the demand. That means that new varieties and agronomic practices must spread, and that new lands must come into production. It also means that pests and flooding must be controlled or their effects minimised and that, in an era of inflation and rising prices, the costs of technological inputs such as fertilisers must be reduced.

One of the chief reasons that the success of the Green Revolution has been limited so far is that the total anea in which the new seed varieties and agronomic practices were applied has been small. In the case of rice, the high yielding varieties were semidwarf types suitable only for shallow water regions (depth approximately $5-50 \mathrm{~cm})$. These lands constitute only $25-30 \%$ of the world's total rice lands and even in these regions, of course, the new varieties are not grown exclusively. The Green Revolution has scarcely touched the other rice-growing areas-the uplands and regions of intermediate and deep water that together comprise $65-70 \%$ of the total available rice lands.

The International Rice Research Institute (IRRI) in the Philippines, where the new varieties and technology were developed, is at present working, in collaboration with rice scientists and growers elsewhere, to extend the Green Revolution to the majority of the world's rice-growing areas-and to solve some of the other problems that limit rice production. Some of them feel that rice production could be doubled throughout the world within the next 15 years through such methods. According to Dr Gurdev Kush, head of the IRRI's plant breeding department, the situation is not that gloomy when the available resources are considered. The problem is exploitation of the resources.

The really limiting factors in food production are political, Dr Kush believes, and in addition vast areas of Africa and Latin America have not been exploited. "I'm convinced," he

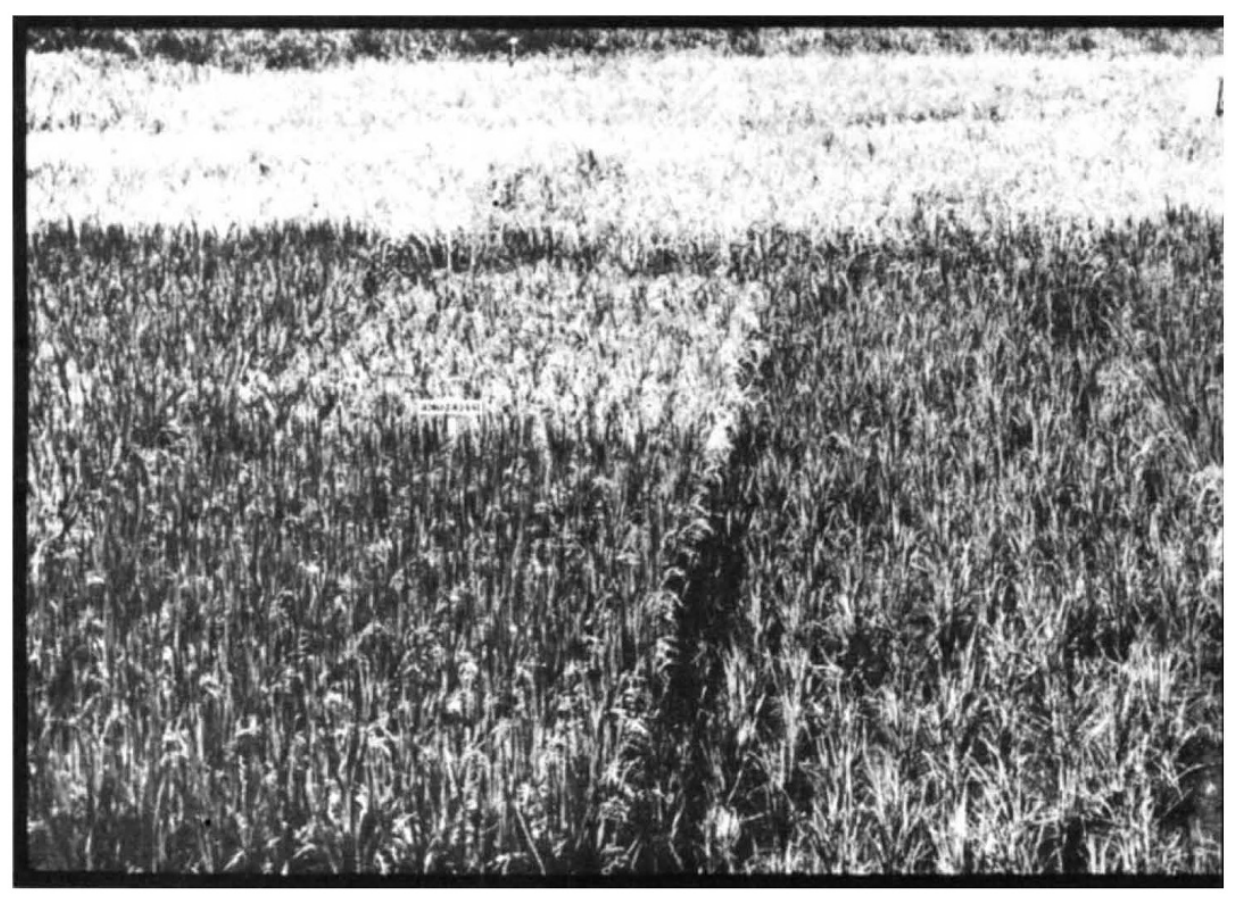

says, "that if there's no major economic upheaval, and provided population control programmes are maintained, we can keep up with demand for the next $15-20$ years."

One of the rice-growing sectors of the world being looked at with special interest by IRRI scientists contains the deep water regions, because these are among the most heavily populated anywhere. People have lived for centuries along the deltas of the mighty rivers of Asia-the Ganges, the Brahmaputra, the Godavari, the Irrawaddy, the Cheo Phraya and the Mekong-because of the adequate supply of water and the rich silt deposits.

Often, floating rice is the only food crop that farmers can grow in these areas, but the tall varieties found there are low yielding: for decades they have produced only 1 or 2 tons a hectare. Almost $10 \%$ of the rice land in Asia and Africa is planted with floating rices, whereas almost half the total rice land has tall non-floating varieties that are adapted to medium-deep water.

Last summer, the first International Seminar on Deep Water Rice was held at the Bangladesh Rice Research Institute north of Dacca-just after flood waters had destroyed much of that country's rice crop. The disaster served as an object lesson for the group, which surveyed both the flood damage and deep water rice culture from helicopters and boats, noting fields where semi-dwarf and even tall varieties were submerged and killed in fields adjoining flourishing deep water rice.

These floating varieties have developed genetic mechanisms that allow them to grow normally in deep water and to escape flood submergence-their stems elongate (for reasons not under- stood) as waters rise and their leaves float on the surface. Rice scientists are now incorponating this genetic characteristic into semi-dwarf and intermediate statune rices, hoping to develop high yielding varieties that can survive floods. Several thousand hectares of an IRRI strain known as IR442-2-58 are now being grown in West Bengal, India, where flood waters often reach a depth of $1 \mathrm{~m}$. Mone than 40 other crosses have been made between floating and semi-dwarf types, and progeny are being tested in Bangladesh, India, Vietnam, Indonesia and Thailand. The headquarters for the deep water programme is at the Hunter Deep Water Rice Research Centre in Thailand.

"Not many scientists are really experts on deep water rice, despite the extent of the deep water areas and the huge populations they suppont," says Dr Mohammed Amirul Islam, Dinectior of the BRRI. "This makes it all the more important that attention be focused on the urgent problems of deep water rice."

Other rice types being developed are varieties that will not elongate like floating rices, but will withstand submergence for a few days under flood conditions. These varieties would be useful where flooding is temporary: the floating varieties might lodge (topple over) as floodwaters recede. The need is illustrated by an incident in the Philippines in 1972, where about 230,000 hectares of rice land were flooded in early growth stages for four weeks, causing a crop loss of about $\$ 74$ million.

Still other varieties of rice are being developed to adapt to the opposite of flood conditions: drought. About 10 $15 \%$ of the world's rice-growing areas 


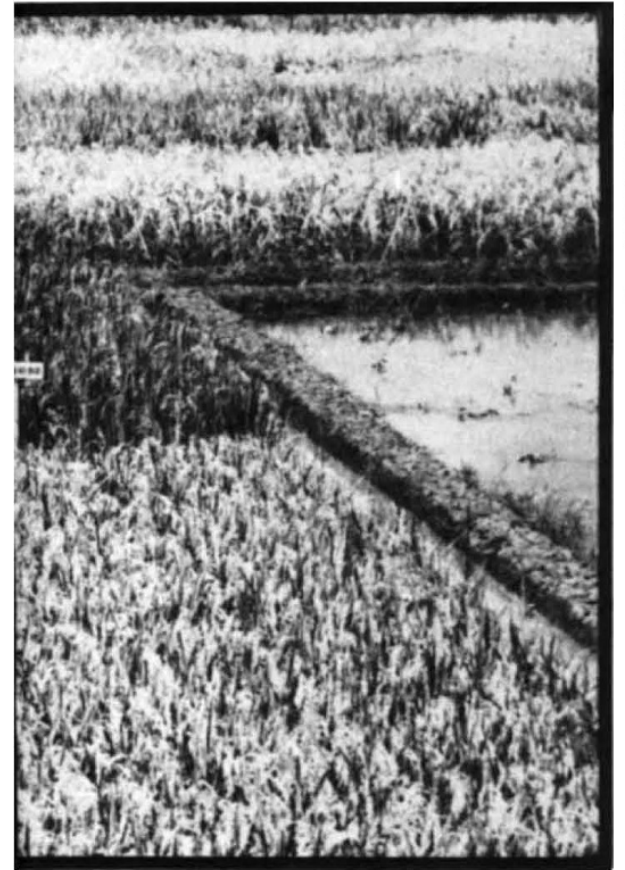

suffer finom insufficient water supply, for example in the uplands. Varieties tolerant to drought are being sought that will, nevertheless, recuperate quickly when the rains come, for areas of varied rainfall. Many regions of the world are too cold for the new varieties yet local rices gnow there. Scientists at the IRRI are now gathering seeds firom these rices and growing them in ice water to see which ones will survive and then to try to cross breed them.

The IRRI calls this programme of rice improvement the Genetic Evaluation and Utilisation Program (GEU). It brings together not only plant breeders but pathologists, entomologists, soil chemists and agronomists in order to identify and evaluate systematically rice genetically adapted to the most pressing constraints on rice production.

Besides the attributes mentioned, the programme seeks to incorporate these other factors into new high yielding varieties: resistance to insects, resistance to diseases, high protein levels and tolerance to toxic soils. In addition scientists are screening rice varieties to determine which use fertiliser and other agricultural chemicals most efficiently, and how best to deliver the chemicals.

It has been found, for example, that, if fertiliser is incomporated in a kind of mud pellet and placed near the plant's roots, about half the amount of fertiliser normally used will produce the same yield. In other words, the method doubles the efficiency of the chemicals. The difficulty is to package the fertiliser and insecticide together in a suitable way and to persuade industry to produce it.

Some success has already been ac- hieved with disease and insect resistance. Early this year the IRRI named three early maturing rice varieties (IR 28,29 and 30 ) as being resistant to a number of diseases and insects. They are the only known varieties highly resistant to grassy stunt virus disease, a serious problem in many countries. The varieties IR 28 and IR 29 are also resistant to tungro, bacterial blight and blast diseases; IR 30 is resistant to tungro and bacterial blight but moderately susceptible to blast. And all three varieties are resistant to brown plant hoppers and green leaf hoppers and moderately resistant to stem borers.

Furthermore, IR 28 and IR 30 mature in only 105 days and IR 29 in 115 days, compared with about 160 days for traditional tropical varieties and 130 for most high yielding varieties. These short seasons should enable farmers in some areas to adopt multiple cropping systems, thus cutting their risks. Varieties that mature in shorter periods are less likely to be damaged by insects or disease or weather simply because they are in the field for a shorter time. In addition, some farmers might fit in an extra crop this way.

Bad soil conditions prevent farmers from growing rice on millions of hectares. Felix Ponnamperuma, a Ceylonese soil chemist at the IRRI, visited Bombay and found that just 10 miles outside the city there were 100,000 hectares of land ideally suited to rice cultivation yet unusable because of salinity, whereas inside the city people were dying of malnutrition. This is flat, alluvial sail, and there is water throughout the year. There are about 10 million hectares of saline soils in India and Pakistan.

In Indonesia new lands are being opened up, says Dr Ponnamperuma, but they are largely peaty bogs. The country hopes to open up five million hectares in the next 10 years, but they contain problem soils, and rice does not grow well on them. In all there are about 40 million hootares in the tropics composed of these marsh soils, mostly in South-ast Asia.

Scientists now are studying the deficiencies of these soils-deficiencies that include almost all the major nutrients and some trace elements. Even when these elements are added they have found that rice growth is not as good as it should be, probably because of the presence of organic toxins. "So we want to breed varieties adapted to these conditions," says Dr Ponnamperuma. "We are trying to tailor the crop to the soil rather than the reverse."

Problems include acid sulphate soils (in perhaps 15 million hectares on which rice cannot be grown in Vietnam and Thailand); iron toxicity when certain soils are flooded (affecting 10-50 million hectares of rice soils), retarding growth and limiting yield; and zinc deficiency (affecting 500,000 hectares in the Philippines and large areas of Pakistan and India). The IRRI found in the Philippines that zinc deficiency sometimes prevented rice growth alto gether, but that dipping seedling roots in zinc oxide and water was the answer. (Only \$1 worth of zinc oxide per hectare (1 kilogram) often produced higher yields than 550 kilograms of complete fertiliser). And with zinc oxide seedling dip, any of the modern varieties of rice could produce twice the yield of the local varieties, even without any other fentiliser.

$A$ third of mankind-1,300 million people-depend on rice for more than half their food. Ninety percent of the low income people of the most densely populated regions of the world rely on it, people whose average income is only $\$ 80$. The efforts of the world's rice scientists will be crucial to their survival in the years ahead.

Resistance ratings of IRRI varieties

\begin{tabular}{|c|c|c|c|c|}
\hline \multirow[b]{2}{*}{ Voriety } & \multicolumn{4}{|c|}{ Diseoses } \\
\hline & Blost & $\begin{array}{c}\text { Bocterind } \\
\text { blight }\end{array}$ & $\begin{array}{c}\text { Grassy } \\
\text { stunt }\end{array}$ & Tungro \\
\hline IR8 & MR & $S$ & $S$ & $\mathrm{~S}$ \\
\hline IR5 & S & $S$ & $\mathrm{~S}$ & $S$ \\
\hline IR2O & MR & & $\mathrm{S}$ & B. \\
\hline IR22 & $\mathrm{S}$ & & $\mathrm{S}$ & $\mathrm{S}$ \\
\hline IR24 & $\mathrm{S}$ & $S$ & $S$ & MR \\
\hline IR26 & MR & $R$ & MS & fi \\
\hline IR28 & & 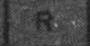 & $R$ & $R$ \\
\hline IR29 & & 8 & - $R$ & $R$ \\
\hline IR30 & MS & A & $R$ & Fा \\
\hline
\end{tabular}

\begin{tabular}{|c|c|c|}
\hline \multicolumn{3}{|c|}{ Insects } \\
\hline $\begin{array}{c}\text { Green } \\
\text { leaf- } \\
\text { nopper }\end{array}$ & $\begin{array}{c}\text { Brown } \\
\text { plant- } \\
\text { hopper }\end{array}$ & $\begin{array}{c}\text { Stem } \\
\text { borer }\end{array}$ \\
\hline$R$ & $S$ & $M S$ \\
\hline$R$ & $S$ & $S$ \\
\hline$R$ & $S$ & $M R$ \\
\hline$S$ & $S$ & $S$ \\
\hline$R$ & $S$ & $S$ \\
\hline$R$ & $R$ & $M R$ \\
\hline$R$ & $R$ & $M R$ \\
\hline$R$ & $R$ & $M R$ \\
\hline$R$ & & $M R$ \\
\hline
\end{tabular}

\begin{tabular}{|c|c|c|c|}
\hline \multicolumn{4}{|c|}{ Soil problems } \\
\hline $\begin{array}{l}\text { Alkalı } \\
\text { injury }\end{array}$ & $\begin{array}{l}\text { Solt } \\
\text { injury }\end{array}$ & $\begin{array}{c}\text { Zinc } \\
\text { defi- } \\
\text { ciency }\end{array}$ & $\begin{array}{c}\text { Phos- } \\
\text { phorus } \\
\text { defi- } \\
\text { ciency }\end{array}$ \\
\hline$S$ & MR & $S$ & MR \\
\hline S & MR & & MR \\
\hline $\mathrm{S}$ & MR & $R$ & \\
\hline $\mathrm{S}$ & $S$ & $S$ & MR \\
\hline$M R$ & MR & S & MR \\
\hline MR & MR & $\mathrm{S}$ & \\
\hline MR & MR & B. & \\
\hline $\mathrm{S}$ & MS & e & \\
\hline MR & MR & & MR \\
\hline
\end{tabular}

$R$ - resistont MH moderntely resiston: $M S_{S}$ : moderately susceptible $S$ - susceptide 